\title{
LEGISLATIVE REFORM OF JUDICIAL REVIEW OF AGENCY ACTIONS
}

\author{
RICHARD J. PIERCE, JR. $\dagger$
}

Sidney Shapiro and Richard Levy have provided an excellent vehicle for discussing the present state of the relationship between agencies and reviewing courts and of potential methods of improving that relationship. ${ }^{2}$ Their study of the history of judicial review of agency action supports their conclusion that many of the legal doctrines applicable to that process are indeteruninate to an unusual degree ${ }^{2}$ - a court often can write an opinion that reverses a major agency action as easily as it can write an opinion that upholds the same action. We do not see, and would not long tolerate, this degree of indeterminacy with respect to the basic doctrines that govern otler fields of law. Imagine, for instance, a world in whicl the concepts of "offer" and "acceptance" are so malleable that parties who attempt to enter into a contract can do no better than to predict that there is a $50 \%$ probability that a court eventually will hold that their conduct created an enforceable contractual relationship. If such a legal environment seems both unimaginable and intolerable, you are in a position to einpathize with a federal agency that must attempt to issue a major rule that is subject to judicial review through apphication of the judicial review provisions of the Administrative Procedure Act (APA). ${ }^{3}$ If the agency does everything it beheves that it must do to issue such a rule, the probabihty that the rule will be upheld is less than $50 \% .{ }^{4}$ Moreover, the variable that best explains the pattern of judicial decisions that uphold or reverse inajor rules is the

$\dagger$ Paul J. Kellner Professor of Law, Columbia University.

1. See Sidney A. Shapiro \& Richard E. Levy, Judicial Inccntives and Indetcrmlnacy in Substantive Review of Administrative Decisions, 44 DUKE L.J. 1049 (1995).

2. Id. at Part II.

3. 5 U.S.C. $\$ \S 701-706$ (1988).

4. Peter H. Schuck \& E. Donald Elliott, To the Chevron Station: An Empirical Study of Federal Administrative Law, 1990 DUKE L.J. 984, 1022 (combining data from 1965,1975 , and $1984-85$ to reveal that reviewing courts upheld only $43.9 \%$ of agency rules). 
ideological composition of the panel of the court that reviews a rule. ${ }^{5}$

Shapiro and Levy demonstrate that the tendency toward doctrinal mdeterminacy in administrative law is so powerful that it seems to be impervious even to unanimous Supreme Court decisions that purport to announce relatively determinate doctrines. ${ }^{6}$ The Court issued unanimous opinions in 1983 and 1984 that practitioners and scholars considered landmarks. ${ }^{7}$ It is at least arguable that both opinions had the potential to create determinate doctrines apphicable to the most frequently hitigated issues in administrative law. ${ }^{8} \mathrm{~A}$ httle over a decade later, Shapiro and Levy are unable to detect any effects attributable to those two decisions. ${ }^{9}$ Through a combination of selective citation, recharacterization of doctrine, and manipulation of categories of disputes, both the Supreme Court and the circuit courts seem to have retained the same high degree of discretion that existed before the Court purported to change the applicable doctrines. ${ }^{10}$

Shapiro and Levy conclude that the judiciary is institutionally incapable of creating determinate doctrines applicable to judicial review of agency actions. ${ }^{11}$ They argue that another institution-Congress--should perform that task. ${ }^{12}$ Shapiro and Levy propose an amendinent to the APA that is designed to replace indetenninate judge-made doctrines with determinate legislative instructions to reviewing courts. ${ }^{13}$ For purposes of my conments, I find it useful to divide the Sliapiro/Levy work into two projects: a scholarly article that attempts to identify a problem and its gene-

5. Richard J. Pierce, Jr., Two Problems in Administrative Law: Political Polarity on the District of Columbia Circuit and Judicial Deterrence of Agency Rulemaking, 1988 DUKE L.J. 300, 303-07 [hereinafter Two Problems in Administrative Law]; see also Richard J. Pierce, Jr., Public Utility Regulatory Takings: Should the Judiciary Attempt to Police the Political Institutions?, 77 GEO. L.J. 2031, 2044 (1989).

6. Shapiro \& Levy, supra note 1 , at Part II.

7. Chevron, U.S.A., Inc. v. Natural Resources Defense Council, Inc., 467 U.S. 837 (1984); Motor Vehicle Mfrs. Ass'n v. State Farm Mut. Auto. Ins. Co., 463 U.S. 29 (1983).

8. Shapiro and Levy take the position that both opinions had that potential. Shapiro \& Levy, supra note 1, at 1064, 1067. As discussed infra text accoinpanying notes 47-97, I agree with their assessment of Chevron, but disagree with their assessinent of State Farm.

9. Shapiro \& Levy, supra note 1, at 1064-65, 1067-68.

10. Id.

11. Id. at 1071 .

12. Id. at 1070 .

13. Id. at 1071-1074. 
sis, and a specific statutory amendment that attempts to address the problem identified in the article.

\section{THE ARTIClE}

Shapiro and Levy reach two major conclusions: (1) the doctrines applicable to judicial review of agency action are indeterminate and manipulable; ${ }^{14}$ and (2) the judiciary is incapable of creating and maintaining determinate doctrines in this area of law. ${ }^{15}$ With a few important qualifications, I accept the accuracy of the first conclusion. ${ }^{16}$ I hope and beheve that the Supreme Court will prove the second conclusion wrong. ${ }^{17}$ I must adimit, however, that the Court's pattern of decisions in recent years provides support for their pessimistic prognosis. ${ }^{18}$ Since the qualifications I would add to their first conclusion follow logically from my application of the model they use to support their second conclusion, I will begin by summarizing that model.

Shapiro and Levy model judicial behavior as a function of two variables: craft norms and outcomes. ${ }^{19}$ All other things being equal, any judge prefers to confornn with craft nornns, i.e., to write an opinion that shows respect for precedents, decisions of higher courts, instructions from legislative bodies, pohicy decisions of pohtically accountable agencies, and the Constitution. If judges were motivated solely by this factor, caselaw would be characterized by a high degree of determinacy, consistency, and predictability. Judges also prefer outcomes that coimcide with their ideological beliefs, however. All other things being equal, any judge prefers an outcome consistent with her ideological beliefs. It follows that a judge will respond to this motivation if she can write an opimion that yields the "correct" outcome while it simultaneously conforms with craft norms. The model predicts that a field of law that is characterized by clear, determinate doctrines will produce a coherent, predictable pattern of outcomes. By contrast, a field that is characterized by indeterminate doctrines will produce an incoherent, un-

14. Id. at 1064-1066, 1067-68.

15. Id. at 1071 .

16. See infra text accompanying notes $25-46$.

17. See infra text accompanying notes 60-97.

18. See Richard J. Pierce, Jr., The Supreme Court's New Hypertextualism: An Invitation to Cacophony and Incoherence in the Administrative State, 95 ColuM. L. REV. (forthcoming April 1995) (manuscript at 22-44, on file with author).

19. Shapiro \& Levy, supra note 1 , at 1051 . 
predictable pattern of outcomes in which the outcome of a specific case depends primarily on the ideological beliefs of the judge who decides the case. ${ }^{20}$

Shapiro and Levy use the same model to predict the nature of the doctrines that are likely to evolve in a field of law. ${ }^{21}$ To the extent that the applicable provisions of statutes and the Constitution are themselves indeterminate, legal doctrine is the product of judicial decisionmaking. If craft norms such as "apply the statute" leave judges with significant discretion to create doctrines applicable to a class of disputes, judges can choose eitler relatively indetermmate doctrines or relatively determmate doctrines. The judicial review provisions of the APA provide judges ample discretion to choose among many potential doctrines applicable to judicial review of agency actions. ${ }^{22}$ In this situation, the model predicts that judges will select relatively deterninate doctrines in fields in which judicial decisions rarely implicate strongly held ideological beliefs, e.g., commercial law, and relatively indeterminate doctrines in fields im which judicial decisions frequently implicate strongly held ideological behefs, e.g., administrative law.

The Shapiro/Levy model is powerful. I lave no criticism of the model. I also agree with many of the inferences that Shapiro and Levy draw through their application of the model to administrative law, and witl many of their assertions with respect to the evidence that corroborates those mferences. In many admimistrative law contexts, the pattern of judicial decisions is incolierent, and the best predictor of the outcome of a review proceeding is the ideological composition of the court that decides the case..$^{23}$

I differ with Shapiro and Levy with respect to some important details, however. I am somewhat more optimistic that the judiciary can, and will, create relatively determmate doctrines applicable to judicial review of agency actions. ${ }^{24}$ I see major differences among the judicial review doctrines that courts presently apply. To identify those differences, I will discuss separately the four doctrines that dommate judicial review of agency actions: (1) the substantial

20. See id. 1057.

21. Id. at 1056-60.

22. See 5 U.S.C. \& 706 (1988).

23. See Two Problems in Administrative Law, supra note 5, at 303-07.

24. See infra text accompanying notes 56-97. 
evidence test; (2) the failure to use proper procedures; (3) the arbitrary and capricious test; and (4) the violation of a statute.

\section{A. Substantial Evidence}

A court is required to uphold an agency action if the agency's findings of fact are supported by substantial evidence, ${ }^{25}$ defined as "such relevant evidence as a reasonable mind might accept as adequate to support a conclusion." ${ }^{26}$ I would not characterize the substantial evidence test as indeterminate. To the contrary, the test is well understood, and the results of its application are easy to predict in the vast majority of cases. ${ }^{27}$ It has also proven to be unusually durable and relatively impervious to manipulation; ${ }^{28}$ the substantial evidence test has existed in its present form for at least forty years. ${ }^{29}$ A 1958 study identified the seven major variables that explained the likely results of application of the test during the $1950 \mathrm{~s}^{30}$ Six of the seven variables are equally valuable predictors of the results of judicial applications of the test in the $1990 \mathrm{~s}^{31}$ With the exception of two brief periods in two specific contexts, courts deserve high marks for constructing and applying this test in a clear and consistent mamier.

Both the relative determinacy of the substantial evidence test and the rare judicial distortions of the test are consistent with the Shapiro/Levy model. The substantial evidence test applies primarily to findings of fact made im agency adjudications. Most agency adjudications do not raise issues that divide judges with differing ideological perspectives. Rulemakings are far more likely to raise

25. 5 U.S.C. $\S 706(2)$ (E) (1988).

26. Consolidated Edison Co. v. NLRB, 305 U.S. 197, 229 (1938); see also Universal Camera Corp. v. NLRB, 340 U.S. 474,488 (1950).

27. See 2 KenNeth CulP DAvis \& Richard J. PIERCE, JR., ADMINISTRATIVE LAW TREATISE, § 11.2 (3d ed. 1994); Richard J. PierCe, JR. et AL., ADMINISTRATIVE LAW \& PROCESS § 7.3.1 (2d ed. 1992). The APA authorizes courts to apply the substantial evidence test only to formal adjudications and formal rulemakings. 5 U.S.C. $\$ 704$ (1988). Some agency-specific statutes, however, require its application to all agency orders, including informal rulemakings. See, e.g., 15 U.S.C. $\$ 717 \mathrm{r}(1988)$. Both the meaning of the test and its effects are less determinate in the context of an informal rulemaking. See 2 DAVIS \& PIERCE, supra, \& 11.4.

28. For a comprehensive discussion of the history of the substantial evidence test, see 2 DAVIS \& PIERCE, supra note 27, \$ 11.2 .

29. See id.

30. Frank E. Cooper, Administrative Law: The "Substantial Evidence" Rule, 44 A.B.A. J. 945, 1002-03 (1958).

31. See PIERCE ET AL., supra note 27, § 7.3.1. 
ideologically charged issues. Moreover, when an adjudication raises such an issue, a judge who disagrees strongly with the agency's resolution of the issue is unlikely to register her opposition to the agency's policy in the form of a reversal of one of the agency's findings of fact. A reversal on that basis would not be a particularly effective way to send the agency a broad inessage of disapproval of its policy. A reversal of an adjudicatory decision based on an alleged misinterpretation of a statute or an alleged violation of the arbitrary and capricious test is far inore likely to further that purpose.

Courts manipulated the substantial evidence test to produce an unusually high rate of reversals of agency adjudicatory decisions in two periods and contexts-NLRB decisions during the 1950 s and the early 1960s, and Social Security Adininistration disability decisions during the 1980s. Those episodes both vahdate the inodel and illustrate the determinacy of the substantial evidence test. They validate the nodel because they took place in unusually politically charged contexts. Labor relations was a controversial field in the $1950 \mathrm{~s}^{32}$ strikes and violent confrontations were common. Many conservatives equated labor unions with socialism. Moreover, inany conservatives believed that the NLRB had been "captured" by labor unions. It follows that conservative judges would attempt to find a way to avoid upholding the decisions of an agency that they perceived to be systematically siding with labor umions. Similarly, social security disability decisionmaking was controversial in the 1980s. Many judges were imcensed at what they perceived to be the heartless policies of the Reagan Administration toward disabled people. ${ }^{33}$ Those judges devised a means of sending the Social Security Administration a broad message of disapproval by reversing an unprecedented proportion of the agency's decisions to deny benefits. ${ }^{34}$ In both cases, reviewing courts liad limited ways of expressing their displeasure with the agencies' policies because both agencies relied primarily on case-

32. See discussion in 2 DAvis \& PIERCE, supra note $27, \S 9.9$.

33. See generally Richard J. Pierce, Jr., Political Control Versus Impermissible Bias in Agency Decisionmaking: Lessons from Chevron and Mistretta, 57 U. Chi. L. Rev. 481, 501-15 (1990) (discussing political control of adjudicative reform in the Social Security Administration).

34. Id. at 518. 
by-case adjudication of individual factual disputes to implement their pohicies.

Those two episodes also illustrate the determinacy of the substantial evidence test. In both cases, the judges who wanted to reverse a high proportion of the agency decisions discovered that they could not do so without explicitly modifying the substantial evidence test. The test was insufficiently malleable to permit its systematic manipulation by result-oriented judges. The judges who were displeased with the NLRB's pattern of decisions in the 1950s reversed a high proportion of those decisions by adopting a special exception to the substantial evidence test. Under the exception, the NLRB could not inake a finding of fact inconsistent with the testimony of a supervisor unless that testimony was inipeached or seriously undermined on cross-exanination. ${ }^{35}$ The judges who were displeased with the Social Security Administration's pattern of decisions in the 1980s adopted another special exception to the test. This exception specified that the agency could not inake a finding of fact inconsistent with the opinions expressed by the applicant's treating pliysician except in unusual circumstances. ${ }^{36}$

Judges who attempt to indulge their preference for particular outcoines by adopting special exceptions to generally applicable doctrines expose themselves both to a high risk of reversal and to a high risk of criticisnts that are predicated on their violation of craft norms. The Suprenie Court reversed the courts that adopted the special rule applicable to NLRB decisions and criticized the judges for departing from craft norms. ${ }^{37}$ The courts that established the special rule applicable to disability decisionmaking in the 1980s retreated from that special rule in the $1990 \mathrm{~s}^{38}$ in response to persistent criticisnis of their departure from craft norms $^{39}$ and a clever tactical counterattack by the agency. ${ }^{40}$ With the exception of these rare episodes, the substantial evidence

35. See, e.g., NLRB v. Walton Mfg. Co., 286 F.2d 16, 25 (5th Cir. 1961), rev'd, 369 U.S. 404 (1962); NLRB v. Florida Citrus Canners Coop., 288 F.2d 630, 636-38 (5th Cir. 1961), rev'd sub nom., NLRB v. Walton Mfg. Co., 369 U.S. 404 (1962).

36. See, e.g., Stieberger v. Bowen, 801 F.2d 29, 31 (2d Cir. 1986); Bluvband v. Heckler, 730 F.2d 886, 892 (2d Cir. 1984).

37. NLRB .v. Walton Mfg. Co., 369 U.S. 404, 407-09 (1962).

38. See, e.g., Schisler v. Sullivan, 3 F.3d 563, 567-68 (2d Cir. 1993).

39. See, e.g., JERRY L. MASHAW ET AL., SOCIAL SECURITY HEARINGS AND APPEALS, 49-53, 57 (1978).

40. The counterattack consisted of issuance of a legislative rule, which the circuit court felt compelled to uphold in Schisler, 3 F.3d at 569. 
test has proven to be reinarkably durable and determinate with respect to its traditional apphication to findings of fact inade in agency adjudications.

\section{B. Procedural Inadequacy}

Since 1978, the courts also have implemented a simple, determinate doctrine applicable to judicial review of the adequacy of the decisionmaking procedures that agencies must use. During the 1960 s and the early 1970s, judges often used their skepticism with respect to the wisdom of the outcoine of an agency proceeding as the unstated basis for holding that the agency's decisionmaking procedures were inadequate in soine respect. ${ }^{41}$ This approach produced inassive indeterminacy since the courts never stated coherent criteria for deciding what procedures an agency was required to use in various circnmstances. The Court brought that practice to an abrupt lalt in Vermont Yankee Nuclear Power Corp. v. Natural Resources Defense Council, Inc. ${ }^{42}$ The Court lield unanimously that a reviewing court cannot reverse an agency action on the basis of an alleged procedural deficiency unless the agency las violated an explicit statutory command or the Constitution. ${ }^{43}$ The Court las never retreated from, or inanipulated, that doctrime, and lower courts adhere to it consistently. The doctrime is determinate and has real bite. Judicial reversals of agency actions predicated on alleged procedural inadequacies declined sigmificantly and permanently after $1978 .^{44}$

This aspect of the law apphicable to judicial review of agency actions is difficult to explain in a maimer consistent with the Shapiro/Levy model. The holding in Vermont Yankee has had a particularly large effect on the class of agency actions that most frequently raise ideologically charged issues-legislative rulemakings. ${ }^{45}$ Moreover, the effect of the holding has been clear: judges lost a significant proportion of their preexisting discretion

41. See, e.g., Mobil Oil Corp. v. Federal Power Comm'n, 483 F.2d 1238 (D.C. Cir. 1973). See generally 1 DAVIS \& PIERCE, supra note 27 , § 7.8.

42. 435 U.S. 519 (1978).

43. Id. at $543-48$.

44. See Sidney A. Shapiro \& Richard E. Levy, Heightened Scrutiny of the Fourth Branch: Separation of Powers and the Requirement of Adequate Reasons for Agency Decisions, 1987 DUKE L.J. 387, 407 n.86.

45. See 1 DAVIS \& PIERCE, supra note $27, \S 7.8$. 
to apply an indeterminate doctrine as a means of indulging their preference for outcomes that are consistent with their ideological perspectives.

The Shapiro/Levy model might be able to explain this aspect of doctrine by reference to the Justices' dedication to craft norms. The craft norm enforced by Vermont Yankee might be stated as follows: it is institutionally inappropriate for judges to apply indeterminate doctrimes as a pretext for rejecting an outcome of an agency proceeding that is imconsistent with the judge's ideological beliefs. I consider that primciple to be an important craft norm. If it is accepted as such, however, it is difficult for the Shapiro/Levy model to explain the existence of any mdeterminate doctrine applicable to judicial review of agency actions. I will return to this problem in my discussion of the doctrine applicable to judicial review of agency interpretations of statutes. ${ }^{46}$

\section{Arbitrary and Capricious}

I accept completely Shapiro and Levy's characterization of the present version of the arbitrary and capricious test as indeterminate. ${ }^{47}$ I an more optimistic about the prospects that the Court will reduce that indeterminacy, however. I also differ with Shapiro and Levy's description of the history of the test.

As Shapiro and Levy note, the version of the arbitrary and capricious test that is applied im administrative law today is the product of a simgle case. In Motor Vehicle Manufacturers Ass'n v. State Farm Mutual Automobile Insurance Co., ${ }^{48}$ the Court described the test in the following manner:

Normally, an agency rule would be arbitrary and capricious if the agency has rehed on factors which Congress has not intended it to consider, entirely failed to consider an important aspect of the problem, offered an explanation for its decision that runs counter to the evidence before the agency, or is so implausible that it could not be ascribed to a difference in view or the product of agency expertise. ${ }^{49}$

\footnotetext{
46. See infra text accompanying notes 78-97.

47. See Shapiro \& Levy, supra note 1, at 1064.

48. 463 U.S. 29 (1983).

49. Id. at 43.
} 
The Court applied that test and held that the agency rule at issue in State Farm was arbitrary and capricious. ${ }^{50}$ The Court concluded unanimously that the agency erred by wholly failing to discuss an obvious alternative to the action taken in the rule. ${ }^{51}$ By a five-tofour margin, the Court also concluded that the agency erred by predicating its rule on an assuined pattern of automobile-driver behavior that was inconsistent with the only studies of driver behavior that were available then to the agency. ${ }^{52}$

In the twelve years since it decided State Farm, the Court lias rarely cited the case and has never since reversed an agency action on the basis of the test announced in State Farm..$^{53}$ Circuit courts cite and apply the State Farm test in slightly less than one-half of the cases to which it applies. ${ }^{54}$ Generally, a reviewing court ignores State Farm when it upholds an agency action and applies the State Farm test when it reverses an agency action. This is the test that best fits the Shapiro/Levy characterization of a doctrine as being so indeterminate that judges routinely mampulate it to support outcoines that are consistent with a judge's ideological perspective.

I disagree with Shapiro and Levy's description of the evolution of the arbitrary and capricious test, lowever. They characterize State Farm as "a more determinate approach to substantive review" and as "a more exact definition of the "arbitrary and capricious' standard." 55 I would cliaracterize State Farm as liaving had the opposite effect: it increased doctrinal indeterminacy.

The arbitrary and capricious test las a long and rich history in the U.S. legal system. In particular, it has been used as the basis for deciding whether a statute violates the Equal Protection Clause or the Due Process Clause. In that context, arbitrary and capricious is used as a synonym for irrational; if a legislative body could rationally believe that the statute might further a legitinate purpose that is within the power of the legislature to further, then

50. Id. at 46 .

51. Id. at 51 .

52. Id. at 54 .

53. I replicated the search described in Shapiro \& Levy, supra note 1, at 1065 n.62. and accompanying text, confirmed their results, and found no cases in which the Court had cited State Farm as the basis for reversing an agency action.

54. See Shapiro \& Levy, supra note 1, at 1065.

55. Id. at 1064. 
the statute must be upheld. ${ }^{56}$ The Supreme Court originally applied this traditional version of the arbitrary and capricious test to agency actions. ${ }^{57}$ As so defined and applied, the arbitrary and capricious test is weak but determinate.

During the late 1960s and the 1970s, circuit courts gradually strengthened the arbitrary and capricious test as it was applied to agency actions. ${ }^{58}$ By 1983, the test had become extraordinarily open-ended. A court could reverse an agency rule witlı which the court disagreed if the court could identify any significant gap, or arguable flaw, im the agency's reasoning process or in the factual or scientific predicates for the agency's action..$^{59}$ Since such flaws and gaps are inevitable in the process of issumg a major rule, the effect of this cliange in doctrine was to confer on judges near total de facto discretion to reverse any rule that was inconsistent with their ideological beliefs. Practitioners, scholars, and circuit court judges interpreted the Court's opinion in State Farm as legitimating the new version of the arbitrary and capricious test that had evolved in circuit courts during the late 1960 s and the 1970 s. $^{60}$ Thus, State Farm transforned a weak, determinate doctrine into a doctrime so indeterminate tliat any judge could manipulate it to obtaim her preferred outcome without violating craft norms.

I do not share Shapiro and Levy's pessimism with respect to the future of this doctrime, however. I expect that the Court will significantly reduce the degree of indeterminacy inherent in the arbitrary and capricious test. The Court may even return to the traditional weak but determinate doctrime that defines arbitrary and capricious as irrational. While the Court lias not applied the State Farm test as the basis for reversing an agency action since it decided State Farm, it lias reversed two circuit court decisions that applied the State Farm test as the basis for reversing agency actions. ${ }^{61}$ The Court used those 1990 and 1991 cases as vehicles to

56. See, e.g., Allied Stores v. Bowers, 358 U.S. 522, 530 (1959).

57. See, e.g., Pacific States Box \& Basket Co. v. White, 296 U.S. 176, $178-80$ (1935).

58. See, e.g., Mobil Oil Co. v. Department of Energy, 610 F.2d 796, 801-02 (Temp.

Emer. Ct. App. 1979), cert. denied, 446 U.S. 937 (1980); National Tire Dealers \&

Retreaders Ass'n v. Brinegar, 491 F.2d 31, 41 (D.C. Cir. 1974).

59. See generally 1 DAVIS \& PIERCE, supra note $27, \S 7.4$.

60. I agree with Shapiro and Levy that the Court's opinion in Citizens to Preserve Overton Park, Inc. v. Volpe, 401 U.S. 402 (1971), had introduced confusion and indeterminacy with respect to the meaning and effect of the arbitrary and capricious test during the years prior to State Farm. Shapiro \& Levy, supra note 1, at 1064.

61. Mobil Oil Exploration \& Producing S.E. Inc. v. United Distribution Cos., 498 
express doubt about the wisdom of the State Farm test and to reduce its scope. ${ }^{62}$ Eight Justices joimed the majority opimions in those cases. The addition of Justice Breyer to the Court probably has sealed the fate of the extraordinarily indeterminate State Farm test. ${ }^{63}$ Justice Breyer has repeatedly criticized the test as illegitimate, as beyond the competence of courts, and as imposing unrealistic demands on agencies. ${ }^{64}$

\section{Statutory Interpretation}

I also agree with Shapiro and Levy's characterization of the doctrine apphicable to judicial review of agency statutory interpretations as being indeterminate, at least to the extent that doctrine is now being apphed by the Supreme Court. ${ }^{65}$ Here again, however, I disagree with their description of the doctrine's evolution. I am also more optimistic tlran Shapiro and Levy with respect to the likelihood that the Court will increase the determinacy of this doctrine.

I agree with Shapiro and Levy that the doctrime apphicable to judicial review of agency interpretations of agency-admimistered statutes was indeterminate until $1984 .{ }^{66}$ The Court used two dramatically different tests to determine whether an agency's interpretation of a statute was permissible; it simply applied one test when it wanted to uphold an agency action and the other when it wanted to reverse an action. This pattern of behavior supports the inference that the Justices were using doctrinal indeterminacy to mask result-oriented decisionmaking. In its opmion in Chevron U.S.A., Inc. v. Natural Resources Defense Council, Inc. ${ }^{67}$ however, the Court purported to replace the prior "choose your test" doctrinal regime with a single, simple test:

U.S. 211, 214-15 (1991); Pension Benefit Guar. Corp. v. LTV Corp., 496 U.S. 633, 647, 656 (1990).

62. Mobil Oil, 498 U.S. at 229-31; LTV, 496 U.S. at 645-46. See Richard J. Pierce, Jr., Seven Ways to Deossify Agency Rulemaking, 47 ADMIN. L. REv. 59, 78-82 (1995).

63. See Richard J. Pierce, Jr., Justice Breyer: Intentionalist, Pragmatist, and Empiricist, 8 ADMIN. L.J. (forthcoming April 1995) (manuscript at 5-8, on file with author).

64. Stephen Breyer, Judicial Review of Questions of Law and Policy, 38 ADMN. L. REv. 363, 382-97 (1986). See also Stephen Breyer, Vermont Yankee and the Court's Role in the Nuclear Energy Controversy, 91 HARV. L. REv. 1833, 1833 (1978).

65. Shapiro \& Levy, supra note 1 , at 1065.

66. See Shapiro \& Levy, supra note 1, at 1049; 1 Davis \& PIERCE, supra note 27, $\S 3.1$.

67. 467 U.S. 837 (1984). 
First, always, is the question whether Congress has directly spoken to the precise question at issue. If the intent of Congress is clear, that is the end of the matter; for the court, as well as the agency, must give effect to the unambiguously expressed intent of Congress. If, however, the court determines Congress has not directly addressed the precise question at issue, the court does not simply impose its own construction on the statute, as would be necessary in the absence of an admimistrative interpretation. Rather, if the statute is silent or ambiguous with respect to the specific issue, the question for the court is whether the agency's answer is based on a permissible construction of the statute. ${ }^{68}$

As Shapiro and Levy note, the Chevron test was widely expected to yield greater determinacy in this important area of law. ${ }^{69} \mathrm{I}$ also agree with their claim that the Chevron test is not presently having this expected beneficial effect. ${ }^{70} \mathrm{I}$ disagree, however, with their description of the reasons why the test has failed to fulfill our initial expectations for it.

Shapiro and Levy say that "the rate of affirmance of agencies in the Supreme Court and the circuit courts is about the same now as (or even lower than) before Chevron was decided."71 This statement suggests that the Chevron test was inherently indeterminate. I have a different interpretation of the data. One year after Chevron, the rate of affirmance of agency actions by circuit courts increased from $70.9 \%$ to $81.3 \% .^{72}$ Moreover, there was a $39.1 \%$ decline in the proportion of cases in which reversal was based on a judicially detected error in an agency's interpretation of a statute that the agency was required to implement. ${ }^{73}$ These data suggest that the Chevron test significantly increased the degree of doctrimal determinacy in the circuit courts. In the last few years, however, this effect of the test has begun to dissipate.

The Supreme Court must take full responsibility for the present failure of the Chevron test to serve its original purpose. The Court began to change its method of applying the test in the 1988-89 Term. $^{74}$ By the 1993-94 Term, the Court had eviscerated

68. Id. at $842-43$ (citations omitted).

69. See Shapiro \& Levy, supra note 1, at 1049.

70. Id. at $1067-68$.

71. Id. at 1068-69 (citations omitted).

72. Schuck \& Elliott, supra note 4, at 1030.

73. Id. at 1033.

74. See Pierce, supra note 18 at 47-48; Thomas W. Merrill, Textualism and the Fu- 
Chevron by adopting new hypertextualist inethods of statutory interpretation that rarely allow a court to conclude that any statute is ambiguous-the predicate for moving to the second step of Chevron. ${ }^{75}$ A plurality of four Justices now appears to place such a high value on allowing judges to indulge their preference for outcomes that conform with their ideological perspectives that they are willing to sacrifice the increased doctrinal determinacy and pohitical accountability the Court originally promised in Chevron to achieve that result. ${ }^{76}$ Now that most circuit courts have a majority of ideologically conservative judges, the conservative Justices appear to prefer that the courts, rather than the politically accountable branches of government, play the dommant role in the policymaking process. ${ }^{7}$ The Justices can further that goal by authorizing judges to attribute fictitious intents to Congress by engaging in creative analyses of statutory language and by ignoring all other evidence that would support either a different interpretation or a conclusion that the statute is ambiguous. ${ }^{78}$ For five reasons, however, I expect the Court to retreat from its recent tendency to infuse ever-increasing indeterminacy in the doctrine apphcable to judicial review of agency interpretations of agency-administered statutes.

First, only four Justices seen to be committed to the new interpretive approach at the present time. ${ }^{79}$ Assuming that each of those Justices retains his present level of commitment, the plurality can implement its agenda only by persuading one or two colleagnes to jom the plurality in each case. The plurahity was successful in accomplishing this task in five of six cases decided during the 1993-94 Term. $^{80}$ The addition of Justice Breyer to the Court is hikely to make this task more difficult, however. Justice Breyer's approach to statutory interpretation is near the other end

ture of the Chevron Doctrine, 72 WASH. U. L.Q. 351, 357-60 (1994); Thomas W. Merrill, Judicial Deference to Agency Precedent, 101 YALE L.J. 969, 983 (1992).

75. See Pierce, supra note 18 , at 6 .

76. The plurality consists of Chief Justice Rehnquist and Justices Scalia, Kennedy, and Thomas. See id. at 6 n.19.

77. See Linda R. Cohen \& Matthew L. Spitzer, Solving the Chevron Puzzle, 57 LAW \& CONTEMP. PROBS. Spring 1994, at 65, 68.

78. See Pierce, supra note 18 , at 23.

79. Id. at 8-22.

80. Id. 
of the spectrum from that of the members of the hypertextualist plurahity. ${ }^{81}$

Second, the hypertextuahist approach is inconsistent with an important craft norm. Its indeterminacy empowers judges to engage in sub rosa substitution of their views of wise policy for the views of politically accountable institutions. ${ }^{82}$ The Court has repeatedly and unanimously embraced a craft norm that disapproves of such a judicial arrogation of policymaking power; ${ }^{83}$ this craft norm was the principal basis for the Court's opmions in Chevron and Vermont Yankee. ${ }^{84}$ The mounting chorus of criticism of the Court for this deviation from an important craft norm will make it increasingly difficult for the hypertextualist plurality to persuade colleagues to join them. ${ }^{85}$ It also may change the minds of one or more members of that plurality; two of the members of the hypertextualist plurality have imdicated their enthusiastic support for this craft norm in the past. ${ }^{86}$

Third, the new approach to statutory imterpretation will produce cacophony and incoherence $m$ the administrative state. ${ }^{87}$ The federal judiciary is characterized by high ideological heterogeneity. If each of the more than 800 federal judges beheves that she is required to divme the one "plam meaming" of each provision of

81. See Stephen Breyer, The 1991 Justice Lester W. Roth Lecture, On the Uses of Legislative History in Interpreting Statutes, 65 S.C. L. REV. 845, 847 (1992) (arguing that courts should not abandon the practice of attempting to ascertain legislative intent when interpreting statutes).

82. See Pierce, supra note 18 , at 49.

83. See, e.g., Chevron, U.S.A., Inc. v. Natural Resources Defense Council, Inc., 467 U.S. 837 (1984); Baltimore Gas \& Elec. Co. v. Natural Resources Defense Council, Inc., 462 U.S. 87 (1983); Vermont Yankee Nuclear Power Corp. v. Natural Resources Defense Council, Inc., 435 U.S. 519 (1978).

84. Chevron, 467 U.S. at 865-66; Vermont Yankee, 435 U.S. at 524-25, 558.

85. See supra notes 75 and 78 and accompanying text; see also Peter Strauss, On Resegregating the Worlds of Statutes and Common Law, 1995 SUP. CT. REV. (forthcoming) (manuscript at 57-59, on file with author); William N. Eskridge, Jr., The New Textualism, 37 UCLA L. REV. 621, 623 (1990) (expounding on what the author calls "the new textualism"-the Court's doctrine giving itself the authority to determine the plain meaning of a statute and to find that legislative history is irrelevant).

86. Chief Justice Rehnquist wrote the opirion for the Court in Vermont Yankee, 435 U.S. at 523. Prior to 1988, Justice Scalia wrote several opinions and a law review article in which he extolled the virtues of the Chevron doctrine. See, e.g., NLRB v. United Food \& Commercial Workers Umion, Local 23, 484 U.S. 112, 133-34 (1987) (Scalia, J., concurring); INS v. Cardoza-Fonseca, 480 U.S. 421, 453-54 (1987) (Scalia, J., concurring); see Antomin Scalia, Judicial Deference to Administrative Interpretations of Law, 1989 DUKE L.J. 511, 512-21.

87. See Pierce, supra note 18 , at 6-7. 
each agency-administered statute, all agencies will soon be subject to a plethora of inconsistent judicial decisions. As this effect of the hypertextuahist approach becomes more apparent, it will attract even more critical attention to the Court's departure from craft norms.

Fourth, the hypertextuahist approach will exacerbate the serious workload problems within the judicial branch. ${ }^{88}$ It will significantly increase the number of intercircuit conflicts that the Supreme Court must resolve. It will also significantly increase the workloads of the circuit courts; it takes a lot of time and effort to draft the kind of intricate and imaginative opinions that are required to support a conclusion that an ambiguous statute has a single plain meaning. Most circuit court judges must decide an average of over one case per day. ${ }^{89}$ They cannot afford to devote scores of hours to the task of writing elaborate opinions in every case that raises a question with respect to the meaning of an agency-administered statute.

Two anecdotes are useful to illustrate the prosaic forces that limit the abihity of the members of the judiciary to use indeterminate doctrines to empower themselves to engage in doctrinal manipulation to achieve the outcomes they prefer. The first comes froin a recent clerk for a circuit court judge. ${ }^{90} \mathrm{He}$ reported numerous conversations in which a judge stated that he had not yet been able to determine the meaning of a statutory provision or in which the members of a panel experienced difficulty reaching agreement with respect to a provision's meaning. After spending a modest amount of time attempting to imterpret the provision or attempting to reach agreement concerning its interpretation, the problem was resolved by using Chevron as a verb, e.g., "Let's Chevron it and move on to a more tractable case." I do not criticize that practice; I applaud it. If a judge cannot determine the meaning of a statute based on a few hours of study, or if a panel cannot reach agreement with respect to its meaning quickly in a

88. See Peter L. Strauss, One Hundred Fifty Cases Per Year: Some Implications of the Supreme Court's Limited Resources for Judicial Review of Agency Action, 87 ColUM. L. REV. 1093, 1096-100 (1987); 1 DAVIS \& PIERCE, supra note 27, § 3.4.

89. The average circuit court judge must decide 372 cases per year. FEDERAL COURTS STUdY COMMITEE, REPORT OF THE FEDERAL COURTS StUdy COMMTTEE 110 (1990).

90. 1994 conversation with a former clerk whose identity I have agreed not to disclose. 
conference, it is highly unlikely that Congress "unambiguously" expressed its intent with respect to the issue. ${ }^{91}$

The second anecdote comes from a circuit judge. ${ }^{22} \mathrm{I}$ delivered a paper in which I noted that the D.C. Circuit consistently reverses agency actions in a higher proportion of cases than does any other circuit. ${ }^{93}$ I suggested several possible explanations for this phenomenon. A judge from another circuit approached me at the coffee break and suggested that I had overlooked the most obvious explanation-the differences in circuit caseloads. He said that in his circuit the workload is so large that he could afford to write the type of long, detailed opimion that is required to reverse an agency action in only a tiny fraction of cases. He stated that he does so in the few cases in which he is confident that the agency had inade a serious error and that he "Chevrons" the rest of the cases in brief opinions upholding the agency action. He suggested that the decades-old problen of the D.C. Circuit's unusually intrusive approach to administrative law could be resolved simply by increasing that circuit's caseload per judge to the point at which it is equivalent to that of other circuits.

Finally, judges and Justices who believe that they can further a substantive agenda by creating and applying indeterminate and lighly manipulable administrative law doctrines are being shortsighted. A strategy of that type can never work for long because the ideological composition of all three branches of government is constantly changing. ${ }^{94}$ Justices who adopt such a strategy will awaken one day to discover that they have empowered their ideological foes and enrasculated their ideological friends. Eventually,

91. See Chevron, U.S.A., Inc. v. Natural Resources Defense Council, Inc., 467 U.S. $837,842-843$ (1984).

92. 1992 conversation with a federal judge whose identity I have agreed not to disclose.

93. See Two Problems in Administrative Law, supra note 5, at 304-05; see also Roy W. McLeese III, Note, Disagreement in D.C.: The Relationship Between the Supreme Court and the D.C. Circuit and Its Implications for a National Court of Appeals, 59 N.Y.U. L. REV. 1048, 1052-60 (1984) (noting that the D.C. Circuit often decides administrative cases in a way that expands judicial involvement and oversight in agency actions); Antonin Scahia, Vermont Yankee: The APA, the D.C. Circuit, and the Supreme Court, 1978 SUP. CT. REV. 345, 359 (criticizing the D.C. Circuit's substitution of an "elaborate, 'evolving, court-made scheme" for the "rudimentary procedural mandates of the APA"); Schuck \& Elliott, supra note 4, at 1041-42 (presenting data that indicate that the D.C. Circuit reverses administrative law cases more frequently than do the other federal courts of appeals).

94. See Pierce, supra note 18 , at $50-51$. 
Justices who attempt to further an ideological agenda im this manner are likely to recognize that the only doctrines that will perform well over time are those that are shaped with reference to the comparative advantages of the institutions of government, rather than with reference to the transient ideological composition of those institutions. ${ }^{95}$ To paraphrase the Chevron opimion, if Congress has directly and definitively resolved an issue, the court must enforce Congress's decision against the President. ${ }^{96}$ When Congress has not acted in that manner, the issue is one of policy that is more appropriately resolved by the President, or by one of his agents, than by a politically unaccountable judge. ${ }^{97}$

\section{The Proposed Statutory Amendment}

Because of their pessimism with respect to the likelihood that the courts can, or will, create reasonably determinate doctrines applicable to judicial review of agency actions, Shapiro and Levy urge Congress to perform this task by enacting a statutory amendment to the APA. ${ }^{98}$ Given my somewhat more optimistic prognosis with respect to a potential judicial solution to this serious problem, I am less enthusiastic about their proposed legislative solution. Proposing a legislative solution to a problem is a risky business. If the political environment in the House and Senate is not "just right" when the proposed amendment is introduced, the result can significantly increase the problem. I would support a legislative solution if (1) I was confident that the statutory language would solve the problem and (2) I was confident that the legislature would be willing to enact such an amendment. I am skeptical witlı respect to the possible existence of either of those conditions.

Congress might be willing to enact an amendment to the APA of the type proposed by Shapiro and Levy solely because such an amendment would be likely to inprove the perforinance of the governinent. This reason inight be enough to carry the day, but I

95. For an excellent analysis of these problems of institutional choice, see NEIL $\mathrm{K}$. KOMESAR, IMPERFECT ALTERNATIVES: CHOOSING INSTITUTIONS IN LAW, ECONOMICS, AND PUBLIC POLICY (1994).

96. Chevron, U.S.A., Inc. v. Natural Resources Defense Council, Inc., 467 U.S. 837, 842-43 (1984).

97. Id. at $865-66$.

98. Shapiro \& Levy, supra note 1, at 1071-72. 
doubt it. Legislators tend to be more motivated by the desire to obtam their ideologically preferred outcomes than are judges and Justices. Unlike members of the judiciary, legislators are not constrained by the countervailing desire to adhere to craft norms. I suspect that the newly empowered Republican majority in Congress would be unenthusiastic about a proposal that would reallocate power from the Republican-dominated judiciary to the Democratic President. Indeed, Congress seems enthusiastic instead about the prospect of enacting amendments to the APA that would have the opposite effect. The extensive amendments to the APA included in the Job Creation and Wage Enhancement Act of 1995 would have the effect of dramatically increasing the discretion of judges to reverse agency actions that are imconsistent with their ideological beliefs. ${ }^{99}$ A legislative reform of the type urged by Shapiro and Levy would have little chance of enactment except in relatively unusual conditions, e.g., when both Congress and the White House are controlled by one party, and the judiciary is dommated by meinbers of the other party.

Even if the pohtical preconditions for beneficial legislative reform exist at some future time, the task of drafting such an amendment is both important and difficult. Shapiro and Levy propose a new APA section 706:100

\section{$\S 706$. Scope of Review}

The reviewing court shall ... (2) hold unlawful and set aside agency actions, findings, and conclusions if the court determines that

(A) the agency decision violates a constitutional right, power, privilege, or immunity;

(B) the agency decision was made without observance of procedure required by law;

(C) the agency decision violates its statutory mandate or other statutory provisions because:

(1) the issue has been specifically resolved by explicit statutory language;

(2) the issue has been specifically resolved by legislative history manifesting an unmistakable congressional intent; or (3) a contrary interpretation of the statute is unequivocally required by the traditional tools of statutory construction;

99. See Titles III and VII of the Job Creation and Wage Enhancement Act, introduced by House Republicans in January 1995. H.R. 9, 104th Cong., 1st Sess. (1995).

100. See Shapiro \& Levy, supra note 1, at 1071-72. 
(D) the agency has not offered a valid policy explanation for its decision because:

(1) it relied on policy concerns that were precluded by statute; or

(2) entirely failed to consider an important aspect of the problem; or

(E) the agency has not offered a logically collerent explanation in terms of agency expertise, credibility determinations, or policy considerations, of

(1) why the evidence in the record supports its decision; or

(2) why the contrary evidence does not preclude the decision.

Subsection (C) addresses judicial review of agency statutory interpretations. In that section, Shapiro and Levy rely primarily on two drafting techniques. First, they disaggregate the factors that courts now consider together in the process of reviewing agency interpretations of statutes. Thus, their amendinent has separate instructions for statutory language, legislative history, and "traditional tools of statutory construction." 101 I am not sure whether this change in language would make the process of judicial review more or less determinate. What if a court concludes that the statutory language points one way, while the legislative history points another way, and an apphicable canon of construction suggests yet a third interpretation?

Shapiro and Levy rely on a second drafting technique in an apparent effort to avoid this problem. They rely on a series of adjectives and adverbs that instruct reviewing courts to uphold the agency interpretation unless the court is confident that the agency is wrong. Thus, statutory language can justify a reversal only if it is "specific" and "exphicit"; legislative history can have that effect only if it is "specific" and "unmistakable"; while "traditional tools," like canons of construction, can support reversal only if that result is "unequivocally required."

I understand their reasons for choosing this drafting technique, but I am not sure whether it will work. There are at least two questions relevant to the likely efficacy of this approach. First, will courts take the adjectives and adverbs seriously? Sometimes they do, and sometimes they don't. A high proportion of the present indeterminacy of the doctrines applicable to judicial review of

101. 5 U.S.C. $\S 553(\mathrm{c})$ (1988). 
agency actions is attributable to the unwillingness of courts to take seriously the adjectives "concise" and "general" that modify the APA \& 553(c) requirement that an agency incorporate in each rule a "concise general statement of its basis and purpose."102 Courts frequently reverse agency rules because of some alleged inadequacy in a several-hundred page statement of basis and purpose. The D.C. Circuit has warned practitioners and agencies not to take seriously the adjectives "concise" and "general."103 I am not confident that the courts would take seriously adjectives like "specific" when they are unwilling to take seriously adjectives like "concise" and "general."

Second, what should a court do if it concludes that statutory language "specifically" and "explicitly" resolves an issue one way, while legislative history "specifically" and "unmistakenly" demonstrates that Congress intended a different resolution of the issue? This is not a fanciful question. In four of the seven statutory interpretation cases decided during the 1993-94 Term, a majority of the Court concluded that the "plain language" of a statute compelled an interpretation that was inconsistent both with the agency's longstanding interpretation and with the "explicit" legislative history that manifested an "unmistakable" contrary legislative intent. ${ }^{104}$

Shapiro and Levy rely in part on the same combination of drafting techniques in subsection (D). That section addresses two of the four parts of the State Farm version of the arbitrary and capricious test-failure to consider an important aspect of a problem and reliance on policy concerns that are precluded by statute. There is a critical omission in this section, however. An agency can be reversed if "it relied on policy concerns that were... precluded by statute." 105 I have inserted an ellipse where I believe the adverb "explicitly" must be added. As Jerry Mashaw and David Harfst have demonstrated, it is unreahistic to expect Congress to include in any statute a comprehensive hist of the policy

102. Id; see 1 DAVIS \& PIERCE, supra note 27, \& 7.4, at 310-12.

103. See Automotive Parts \& Accessories Ass'n v. Boyd, 407 F.2d 330, 338 (D.C. Cir. 1968).

104. See Director, Office of Workers' Compensation Programs v. Greenwich Collieries, 114 S. Ct. 2251 (1994); City of Chicago v. Environmental Defense Fund, 114 S. Ct. 1588 (1994); NLRB v. Health Care \& Retirement Corp. of America, 114 S. Ct. 1778 (1994); Central Bank of Denver, N.A. v. First Interstate Bank of Denver, N.A., 114 S. Ct. 1439 (1994). All four cases are discussed in Pierce, supra note 18, at 8-22.

105. Shapiro \& Levy, supra note 1 , at 1072 (quoting $\S(2)(D)(1)$ of the proposed statute). 
concerns that any agency should consider in taking any action. ${ }^{106}$ Thus, it would be a serious error, for instance, to interpret a statute as precluding agency consideration of the potential adverse economic effects, environmental effects, or national security effects of a proposed action simply because Congress neglected to mention one of those widely shared social values in a particular statute. An agency should not be forbidden from relying on a policy concern except in the rare case in which Congress explicitly forbids it from doing so.

Subsection (E) seeins to be intended to address the otlier factors that are made relevant by the State Farm version of the arbitrary and capricious test, as well as to restate the substantial evidence test in a new form. This section needs a lot of work. I can not begin to predict the manner in which it would be interpreted in the myriad contexts to which it would be applied.

As it is presently drafted, subsection (E) would create more problems than it solves. Three questions suggest the nature and inagnitude of the interpretive problems that subsection $(E)$ would raise. First, does it require an agency to support each factual predicate for a rule witl evidence in the rulemaking record? It seems to require the agency to do so. That is not the law at the present time, ${ }^{107}$ and such a requirement would create major problems in the common situation in whicl no data exists to support, or to refute, a factual relationship that the agency believes to exist based on the agency's expertise in a field. ${ }^{108}$ Second, what is a "logically coherent explanation"109 for a rule? In the hands of judges witl strong ideological predilections, this standard could prove as inalleable as the requirement of reasoned decisionmaking announced in State Farm. For instance, a decision to substitute a marketable emission permit system for traditional command and control regulation of emissions will seem unore logical and colierent to a conservative than to a hiberal. Third, why recodify the

106. Jerry L. MAShaw \& David L. Harfst, The Struggle for Auto SafeTy 202-23 (1990). See also Pierce, supra note 62, at 79-80.

107. See Baltimore Gas \& Elec. Co. v. Natural Resources Defense Council, Inc., 462 U.S. 87, 97, 103 (1983); FCC v. WNCN Listeners Guild, 450 U.S. 582, 596 (1981). See generally PIERCE ET AL., supra note 27, § 7.3.4 (discussing judicial deference to agency policy decisions concerning unknowable facts).

108. See 1 DAVIS \& PIERCE, supra note 27, § 7.5.

109. Shapiro \& Levy, supra note 1 , at 1072 (quoting $\S(2)(E)$ of the proposed statute). 
substantial evidence test? The doctrine that has been spawned by the substantial evidence provision of section 706 has proven to be both determinate and durable. ${ }^{110}$ The recodification of that test in proposed subsection (E) would force courts to begin anew the multi-decade process of imterpreting a complicated new combination of words. I cannot predict the ultimate result of that process, but I doubt that it would be an improvement over the status quo. Moreover, uncertainty with respect to the meaning of the new words would be a source of confusion, litigation, and indeterminacy for the decades that would be required to obtain definitive interpretations from the judiciary.

My purpose is not to criticize Shapiro and Levy's drafting ability. I doubt that I could draft a better replacenient for the current section 706. My criticism is intended instead to illustrate the extreme difficulty of writing detailed instructions to reviewing courts that offer a realistic prospect of enhanced determinacy with respect to the doctrimes apphicable to judicial review of agency actions. I am not sure it is possible to improve on the performance of the wise men who devoted many years to the process of draftmg the present version of section $706 .{ }^{111}$ It is certainly possible for the courts to improve their performance in interpreting and applying that section. But I am cautiously optimistic that the Supreme Court will move in that direction over the next few years.

110. See supra text accompanying notes $25-40$.

111. For a discussion of the history of the APA, see 1 DAVIS \& PIERCE, supra note 27, § 1.4. 